\title{
Mesenchymal stem cells and immunomodulation: current status and future prospects
}

\author{
F Gao ${ }^{1,5}$, SM Chiu ${ }^{2,5}$, DAL Motan ${ }^{1}$, Z Zhang ${ }^{1}$, L Chen ${ }^{1}$, H-L Ji ${ }^{3}$, H-F Tse ${ }^{2}$, Q-L Fu ${ }^{\star, 4}$ and Q Lian ${ }^{\star, 1,2}$
}

The unique immunomodulatory properties of mesenchymal stem cells (MSCs) make them an invaluable cell type for the repair of tissue/ organ damage caused by chronic inflammation or autoimmune disorders. Although they hold great promise in the treatment of immune disorders such as graft versus host disease (GvHD) and allergic disorders, there remain many challenges to overcome before their widespread clinical application. An understanding of the biological properties of MSCs will clarify the mechanisms of MSC-based transplantation for immunomodulation. In this review, we summarize the preclinical and clinical studies of MSCs from different adult tissues, discuss the current hurdles to their use and propose the future development of pluripotent stem cell-derived MSCs as an approach to immunomodulation therapy.

Cell Death and Disease (2016) 7, e2062; doi:10.1038/cddis.2015.327; published online 21 January 2016

\section{Facts}

- Mesenchymal stem cells (MSCs) are multipotent stem cells that can differentiate into a variety of cell types, and be isolated and expanded easily in vitro.

- Preclinical and clinical studies show that MSCs have antiinflammatory and immune-privilege potential.

- Several MSC products have been approved for clinical application: Cartistem for degenerative arthritis, Cupistem for anal fistula in Korea and Prochymal for acute GvHD in Canada and New Zealand

\section{Unresolved Issues}

- An understanding of the mechanisms of MSC-based immunomodulation remains incomplete.

- The possible reasons for the mixed results of MSC immunomodulation therapies in clinical trials require further scientific clarification.

- There remain challenges to the future development of MSCs for immunomodulation and a need for improved quality control.

\section{MSCs and Immunomodulation}

Mesenchymal stem cells (MSCs) are multipotent stem cells that can differentiate into a variety of cell types, including adipocytes, osteoblasts, chondrocytes, myocytes, $\beta$-pancreatic islets cells and, potentially, neuronal cells. In addition to their differentiation potential, MSCs have been reported to regulate the immune response in many diseases. ${ }^{1-8}$ Numerous reports have shown that adult MSCs can affect the immune T- and B-cell response: (1) adult MSCs suppress T-cell proliferation, cytokine secretion and cytotoxicity and regulate the balance of Th1/Th2;;,9,10 (2) adult MSCs regulate the functions of regulatory T cells (Tregs); ${ }^{11}(3)$ MSCs increase B-cell viability but also may inhibit their proliferation and arrest the cell cycle; in addition, MSCs affect the secretion of antibodies and production of co-stimulatory molecules of $\mathrm{B}$ cells; ${ }^{12}(4)$ MSCs inhibit the maturation, activation and antigen presentation of dendritic cells; ${ }^{13,14}$ and (5) adult MSCs also inhibit interleukin-2 (IL-2)-induced natural killer (NK) cell activation. ${ }^{15}$

Similar to adult MSCs, pluripotent stem cell-derived MSCs such as embryonic stem cells (ESCs) or induced pluripotent stem cells (iPSCs), that is, ESC-MSCs or iPSC-MSCs, also demonstrate strong potential for immunomodulation by inhibition of lymphocyte proliferation ${ }^{16-18}$ and NK cells. ${ }^{18}$ Furthermore, ESC-MSCs suppress proliferation of responder T lymphocytes, including $\mathrm{CD} 4^{+}$or $\mathrm{CD} 8^{+} \mathrm{T}$ cells. ${ }^{16,17}$ They also suppress the cytotoxic effects of activated NK cells and downregulate NK-activating receptors. ${ }^{17}$ Our recent studies have shown that IPSC-MSCs can inhibit phytohemagglutinin-

\footnotetext{
${ }^{1}$ Department of Ophthalmology, Li Ka Shing Faculty of Medicine, The University of Hong Kong, Hong Kong; ${ }^{2}$ Department of Medicine, Li Ka Shing Faculty of Medicine, The University of Hong Kong, Hong Kong; ${ }^{3}$ Department of Cellular and Molecular Biology, University of Texas Health Science Center at Tyler, Tyler, Texas 75708, USA and ${ }^{4}$ Otorhinolaryngology Hospital, The First Affiliated Hospital, Sun Yat-sen University, Guangzhou, Guangdong, China

*Corresponding author: Q-L Fu, Otorhinolaryngology Hospital, The First Affiliated Hospital, Sun Yat-sen University, 58 Zhongshan Road II, Guangzhou, Guangdong 510080, China. Tel: +86 13699725962; Fax: +86 020 87333733; E-mail: fuqingl@mail.sysu.edu.cn

or Q Lian, Department of Medicine, Department of Ophthalmology, The University of Hong Kong 5 Sassoon Road, Hong Kong. Tel: +852 2831 5403 ; Fax: +852 2816 2095; E-mail: qzlian@ @ku.hk

${ }^{5}$ These authors contributed equally to this work.

Abbreviations: BM, bone marrow; iPSC, induced pluripotent stem cell; CCR7, cytokine receptor 7; iNOS, inducible nitric oxide synthase; COX2, cyclooxygenase 2; MSC, mesenchymal stem cell; GMP, good manufacturing practices; NK, natural killer cell; GvHD, graft versus host diseases; NO, nitric oxide; hESC, human embryonic stem cell; OVA, ovalbumin; HGF, hepatocyte growth factor; PGE2, prostaglandin E2; HLA, human leukocyte antigen; SLE, systemic lupus erythematosus; IDO, indoleamine 2, 3dioxygenase; TGF- $\beta$, transforming growth factor- $\beta$; IFN- $\gamma$, interferon- $\gamma$; TNF- $\alpha$, tumor necrosis factor- $\alpha$; IL-10, interleukin-10; Treg, regulatory T cell

Received 30.7.15; revised 13.9.15; accepted 25.9.15; Edited by H-U Simon
} 
stimulated lymphocyte proliferation in a dose-dependent manner. ${ }^{19}$

Interestingly, current evidence suggests that MSCs exert variable immunomodulatory effects on the same types of immune cell depending on the local microenvironment or disease status. For example, MSCs decrease the Th1 response in patients with acute graft versus host disease $(\mathrm{GvHD})^{20}$ and autoimmune diseases such as systemic lupus erythematosus (SLE). ${ }^{21}$ However, bone marrow (BM)-derived MSCs (BM-MSC) lead to a shift from Th2 to Th1 responses in airway allergic inflammatory diseases, including allergic rhinitis $^{22,23}$ and asthma. ${ }^{24-27}$ Inflammatory conditions also have been proven to change immunomudulatory gene expression in MSCs or promote the cell-cell contact effect, resulting in an enhanced immunosuppressive response. ${ }^{28-30}$ These observations suggest that MSCs are capable of switching their effects to protect the body from disease in different situations.

Mechanisms of MSC-mediated immunomodulation. Although the underlying mechanisms of MSC immunomodulation have yet to be elucidated, they are likely mediated by soluble factors and cell contact-dependent mechanisms in response to immune cells (Figure 1). We and others have shown that MSCs regulate the adaptive and innate immune systems by suppression of $T$ cells and maturation of dendritic cells, reducing $\mathrm{B}$-cell activation and proliferation and inhibiting proliferation and cytotoxicity of NK cells, and promote the generation of regulatory $\mathrm{T}$ cells via soluble factors or cell-cell contact mechanisms. ${ }^{19,31-33}$

Immunomodulation by soluble factors: Several soluble factors have been proposed to mediate the immunosuppressive effect, including transforming growth factor- $\beta 1$ (TGF- $\beta 1$ ), prostaglandin E2 (PGE2), hepatocyte growth factor (HGF), indoleamine-pyrrole 2,3-dioxygenase (IDO), nitric oxide (NO) and interleukin-10 (IL-10). Extensive data show that the proinflammatory cytokine interferon- $\gamma($ IFN- $\gamma)$, alone or in combination with tumor necrosis factor- $a$ (TNF- $a$ ), IL-1 $a$ or $\mathrm{IL}-1 \beta$, induces MSCs to secrete various enzymes and soluble factors such as cyclooxygenase 2 (COX-2), PGE2 and IDO that mediate immunosuppressive activity. ${ }^{34-37}$ PGE2, which is dramatically upregulated after co-culture of MSCs with peripheral blood mononuclear cells, ${ }^{38}$ has been shown to inhibit T-cell proliferation. ${ }^{39}$ IDO, by catalyzing the conversion of tryptophan to kynurenine, is able to inhibit the growth and function of immune cells. ${ }^{39}$ Secretion of IDO by MSCs has been shown to inhibit allogeneic T-cell responses and induce kidney allograft tolerance, ${ }^{40}$ although IDO-expressing dendritic cells have also been shown to mediate the inhibitory effect of MSCs on T-cell proliferation. ${ }^{41} \mathrm{NO}$ is another soluble factor known to inhibit T-cell proliferation. ${ }^{42,43}$ It has been shown that MSC-produced NO is one of the major mediators of T-cell suppression by MSCs. ${ }^{44}$ Ren et al. ${ }^{37}$ established that BM-MSCs dramatically upregulated inducible nitric oxide synthase (iNOS) and chemokines in response to a combination of IFN- $\gamma$ and proinflammatory cytokines. They further found that MSCs attenuated delayed-type hypersensitivity and prevented the development of GvHD through a mechanism that required TNF- $a$ and iNOS. ${ }^{37}$ Nemeth et al. ${ }^{25}$ showed that BM-MSCs significantly suppressed allergic responses in a mouse model of ragweed-induced asthma by TGF- $\beta$. In addition to the above mentioned factors, several reports suggest that other soluble factors such as IL- $6,{ }^{43}$ galectins $^{45,46}$ and leukemia inhibitory factor $^{47}$ can regulate immunomodulation of MSCs.

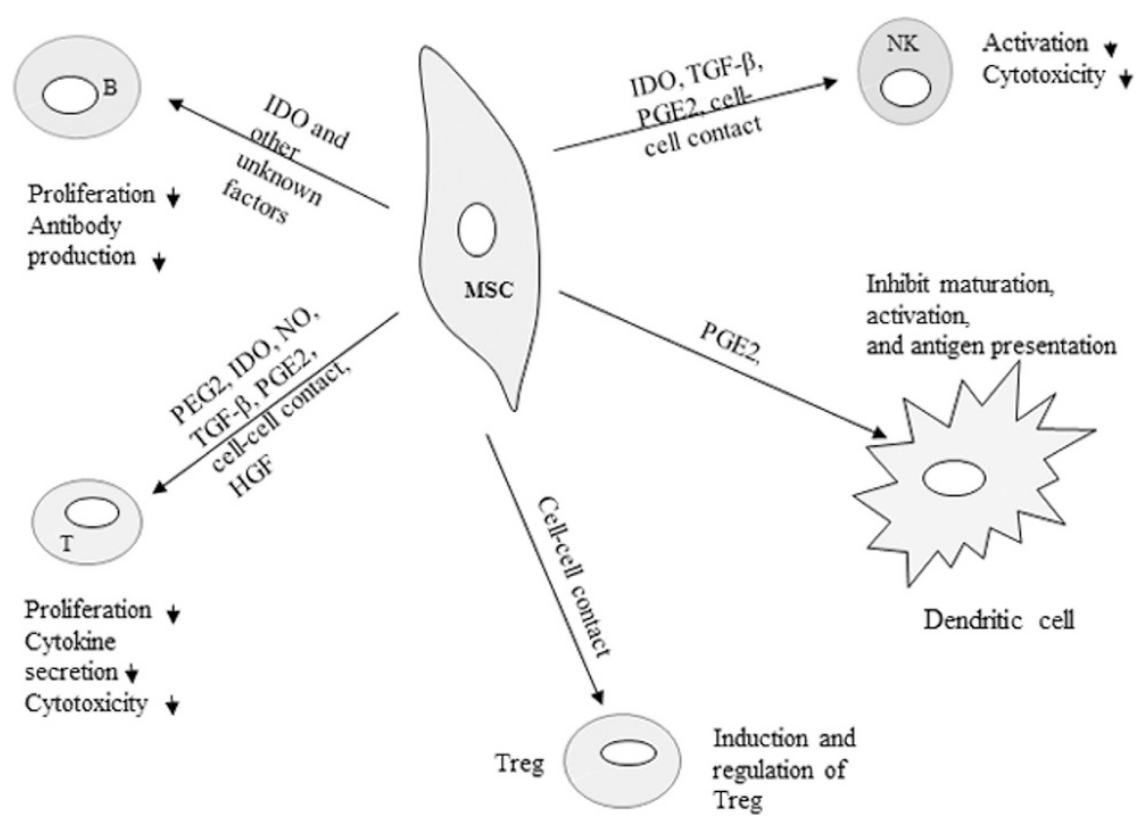

Figure 1 Immunomodulatory effects of MSCs on immune cells. Immunomodulatory effects of MSCs include suppression of B- and T-cell proliferation, induction and regulation of regulatory T cells, inhibition of NK cell function and inhibiting dendritic cell maturation and activation. The immunosuppressive effects of MSCs are mediated by soluble factors and cell-cell contact 
Table 1 Immunomodulation of MSCs in animal model

\begin{tabular}{|c|c|c|c|c|c|}
\hline \multirow[t]{2}{*}{ Model } & \multirow[t]{2}{*}{ Animals } & \multicolumn{3}{|l|}{ MSCs } & \multirow[t]{2}{*}{ Reference } \\
\hline & & Source & Effect & Mechanism & \\
\hline Allergic rhinitis & Balb/c mice & Balb/c mice adipose tissue MSCs & Y & / & 22 \\
\hline Asthma & Balb/c mice and C57BL/6 mice & C57BL/6 mice BM-MSCs & Y & IFN- $\gamma$ dependent & 24 \\
\hline Asthma & C57BL/6J mice & Balb/c mice BM-MSCs & Y & TGF- $\beta$ & 25 \\
\hline Chronic asthma & Balb/c mice & Human BM-MSCs & $\mathrm{Y}$ & / & 26 \\
\hline Allergic rhinitis & Balb/c mice & Human BM-MSCs & Y & / & 27 \\
\hline Autoimmune hearing loss & Balb/c mice & Human adipose tissue MSCs & $\mathrm{Y}$ & IL-10 & 150 \\
\hline Severe asthma & Balb/c mice & S.D. rats BM-MSCs & $\mathrm{Y}$ & I & 55 \\
\hline Asthma & Balb/c mice & Balb/c mice BM-MSCs & $\mathrm{Y}$ & / & 56 \\
\hline Chronic asthma & Balb/c mice & Balb/c mice BM-MSCs & Y & / & 57 \\
\hline Experimental colitis & C57BL/6J mice & Human gingival-MSCs & $\mathrm{Y}$ & IL-10, IDO & 58 \\
\hline Radiation proctitis & SD rats & SD rat BM-MSCs & $\mathrm{Y}$ & Glucocorticoid & 59 \\
\hline Immune thrombocytopenia & Balb/c mice & Human adipose tissue MSCs & $\mathrm{Y}$ & $\mathrm{T}$ helper cells & 60 \\
\hline $\begin{array}{l}\text { Experimental autoimmune } \\
\text { encephalomyelitis }\end{array}$ & C57BL/6 mice & C57BL/6J mice BM-MSCs & $\mathrm{Y}$ & IFN $-\gamma$ & 61 \\
\hline Experimental arthritis & DBA/1 LacJ mice & Human adipose tissue MSCs & Y & / & 62 \\
\hline Rheumatoid arthritis & $\mathrm{DBA} / 1$ mice & Human adipose tissue MSCs & $Y$ & Inducing Treg cells & 63 \\
\hline Rheumatoid arthritis & $\mathrm{DBA} / 1$ mice & Human umbilical cord-MSCs & Y & IL-10, IDO, TGF- $\beta$ & 64 \\
\hline SLE & MRL/lpr mice & $\mathrm{C} 3 \mathrm{H} / \mathrm{HeJ}$ mice BM-MSCs & $\mathrm{Y}$ & / & 65 \\
\hline SLE & NZB/W F1 mice & Human umbilical cord-MSCs & $\mathrm{Y}$ & / & 66 \\
\hline SLE & MRL/lpr mice & Human umbilical cord-MSCs & $\mathrm{Y}$ & / & 68 \\
\hline GvHD & $\mathrm{DBA} / 2$ mice & Human umbilical cord-MSCs & Y & IDO, TGF- $\beta$ & 69 \\
\hline $\begin{array}{l}\text { Experimental autoimmune } \\
\text { encephalomyelitis }\end{array}$ & Lewis rats & Lewis rats BM-MSCs & $\mathrm{Y}$ & TGF- $\beta$, IL- 6 & 72 \\
\hline Autoimmune thyroiditis & C57BL/6 mice & Human adipose tissue MSCs & $\mathrm{Y}$ & / & 73 \\
\hline Autoimmune myasthenia & C57BL/6 mice & Human BM-MSCs & $\mathrm{Y}$ & / & 74 \\
\hline Contact dermatitis & Balb/c mice & Human gingival-MSCs & $\mathrm{Y}$ & PGE2 & 151 \\
\hline Asthma & Balb/c OlaHsd mice & FV/BN mice BM-MSCs & $\mathrm{Y}$ & Inducing Treg cells & 152 \\
\hline Asthma & C57BL/6 mice & C57BL/6J mice BM-MSCs & $\mathrm{Y}$ & / 1 & 153 \\
\hline Asthma & Balb/c mice & Balb/c mice adipose tissue MSCs & Y & / & 154 \\
\hline
\end{tabular}

Abbreviations: BM-MSC, bone marrow-derived mesenchymal stem cell; SLE, systemic lupus erythematosus; IFN- $\gamma$, interferon- $\gamma$; IL-10/6, interleukin-10/6; IDO, indoleamine 2,3-dioxygenase; iPS-MSC, induced pluripotent stem cell-derived mesenchymal stem cell; OVA, ovalbumin; PGE2, prostaglandin E2; TGF- $\beta$, transforming growth factor- $\beta$; Treg cell, regulatory $T$ cell; $Y$, effect was shown

Although more than a dozen soluble factors are known to be involved in the immunomodulation of MSCs, their relationship remains unclear. The effect of soluble factors on the activity of MSCs may vary depending on the origin of the MSCs, target cells and the microenvironment. Though it is indisputable that MSC therapy contributes to immunosuppression, further elucidation of the detailed biological mechanisms involved in this process is required. At the same time, it must be noted that some cytokines or chemokines released from MSCs may be harmful, such as TNF- $a$ and IL- 6 that promote an inflammatory response. ${ }^{48}$ Therefore, the regulation mechanism of MSCs to produce beneficial soluble factors and how such factors can modulate immune cells are key issues that underlie the successful immunomodulation effects of MSCs.

Immunomodulation by cell-cell contact: Several reports on culture systems have shown that cell-cell contact is a key factor involved in the immunomodulatory effects of MSCs. Han et al. $^{49}$ found that BM-MSCs not only decrease the survival and proliferation of $T$ cells by contact-dependent mechanisms, but they also increase the proportion of Tregs. Krampera et al. ${ }^{50}$ reported that the inhibitory effect of MSCs on $\mathrm{T}$ cells requires the presence of MSCs in culture and MSC-T-cell contact. In addition, it has previously been found that direct contact between MSCs and purified T cells is required for Treg induction. ${ }^{51}$ Cell adhesion molecules secreted by MSCs, such as CD274 (also known as Programmed death ligand 1), vascular cell adhesion molecule-1 and galectin-1, could be upregulated by IFN- $\gamma$ that not only can support cell-cell contact but also promote the immunomodulation capacity of MSCs. ${ }^{29,30,52-54}$ The interaction between cells and the action or counteraction of several factors involved in the immune function of MSCs is a complex network. In order to provide pleiotropic immunomodulation that is responsive to different stimulants such as chemokines and that targets different immune cells, MSCs are likely to employ both direct contact and soluble factors that work together for diverse and strong regulation.

Preclinical studies of MSCs in immunomodulation. MSCs derived from BM or fat tissues or other tissues have been employed in the treatment for experimental animal models of inflammatory and immune disorder diseases (Table 1). Autologous, allogeneic and even xenogeneic MSCs have shown great promise in the treatment. In mouse models of chronic or severe asthma, systemic administration of MSCs reduces allergen-specific IgE and Th2 cytokines IL-4, IL-5 or IL-13 in bronchial fluid and inhibits airway inflammation and pathology remodeling. ${ }^{55,56}$ A decrease in serum NO levels following administration of MSCs was also observed. ${ }^{57}$ In experimental disease models including colitis, ${ }^{58}$ radiation proctitis, $^{59}$ immune thrombocytopenia ${ }^{60}$ and autoimmune 
encephalomyelitis, ${ }^{61}$ MSCs reduce T-cell proliferation, suppress the inflammatory infiltrates and cytokines and express anti-inflammatory cytokines. Similarly, prominent immunosuppressive effects of MSCs for animal immune disorder models of arthritis, ${ }^{62-64} \mathrm{SLE},{ }^{65-68} \mathrm{GvHD}^{69}$ and multiple sclerosis $^{70-72}$ have been well documented. In the treatment of SLE, both allogeneic BM-MSCs ${ }^{65}$ and xenogeneic umbilical cord blood derived-MSCs from humans ${ }^{66,68}$ significantly delay the development of proteinuria, reconstruct the BM osteoblastic niche and effectively reverse multiorgan dysfunction. MSCs also seem to confer protective effects in other immune diseases including autoimmune thyroiditis, ${ }^{73}$ autoimmune myasthenia gravis, ${ }^{74}$ hearing loss ${ }^{75}$ and primary biliary cirrhosis. ${ }^{76}$

Notably, human MSCs demonstrated effective immunomodulation in mouse models of immune disorders. ${ }^{26,27,58,60}$ As human MSCs are well tolerated in murine disease models, it suggests that human MSCs can favorably change the outcome of inflammatory reactions while avoiding the pathology associated with cross-species application. ${ }^{27,60}$

Human ESC/iPSC-MSCs act as new cell types have also been investigated in immunoregulation and showed encouraging results. ${ }^{19,77-79}$ Human ESC-MSCs exhibited better engraftment and immunomodulation effect than human BM-MSCs in mouse pulmonary arterial hypertension model. ${ }^{79}$ Another study demonstrated the immunomodulatory properties of human iPSC-MSCs in a mouse model of allergic inflammation in both the upper and lower airways. ${ }^{33}$ Systemic administration of human iPSC-MSCs significantly inhibited inflammatory infiltration in both the bronchoalveolar and nasal lavage, and serum levels of IgE and Th2 cytokines (IL-4, IL-5 or IL-13) were also significantly decreased. Interestingly, compared with adult MSCs, human ESC/iPSC-MSCs are insensitive to IFN- $\gamma$-induced human leukocyte antigen-II (HLA-II) and have better cell survival and engraftment rate after transplantation. ${ }^{79,80}$ These advantages of ESC/iPSC-MSCs indicate that pluripotent stem cell-derived MSCs can serve as an alternative to adult MSCs in the future treatment of these diseases.

Clinical studies of MSCs in immunomodulation. A progressive understanding of the biology of MSCs has led to their approval and use in clinical trials as an immunomodulator in the treatment of diseases such as GvHD, organ transplantation, diabetes, multiple sclerosis and Crohn's disease. Detailed information is summarized in Table 2. To date, more than 400 studies to explore the therapeutic effects of MSCs have been registered on the clinical trial database (www.clinicaltrials.gov).

Severe GvHD is a life-threatening complication following allogeneic transplantation of hematopoietic stem cells in many malignant and nonmalignant disorders. Steroids are currently the first-line treatment for GvHD. Nonetheless, the outcome for patients with severe, steroid-resistant or acute GvHD is poor. In a phase II study, Le Blanc et al. ${ }^{81}$ injected allogeneic BM-MSCs into 55 patients with grade 2-4 GvHD: a complete or partial response was achieved in 30 and 9 patients, respectively. More importantly, the total and transplantationrelated mortality in those with a complete response was significantly lower than in those with a partial or no response, and no patients experienced major adverse effects following infusion of MSCs. In another phase I/II clinical trial of the therapeutic effects of MSCs on acute (10 patients) and chronic (8 patients) GvHD, ${ }^{82}$ a complete response was achieved in 1 patient with acute GvHD and 1 with chronic GvHD; a partial response was observed in 6 patients with acute GvHD and 3 patients with chronic GvHD. No major adverse event was observed following MSC therapy. In pediatric patients with chronic GvHD following allogeneic stem cell transplantation, one of three patients showed slight improvement following allogeneic BM-MSC infusion. ${ }^{83}$ Allogeneic BM-MSCs have also been shown by other clinical trials to be beneficial in GvHD. ${ }^{84-88}$ Recently, Health Canada has approved the clinical application of MSCs in patients with GvHD.

Phase I/II clinical trials have evaluated the application of MSCs in patients with multiple sclerosis. ${ }^{89-92}$ In a phase I/II open-safety clinical trial, Karussis et al. ${ }^{91}$ showed that transplantation of MSCs in patients with multiple sclerosis and amyotrophic lateral sclerosis could induce immediate immunomodulatory effects and was a safe and clinically feasible procedure. Another open-label phase II study of autologous MSCs for the treatment of secondary progressive multiple sclerosis demonstrated improved visual acuity and visual evoked response latency with no serious adverse effects. ${ }^{90}$

The therapeutic effects of MSC transplantation have been investigated in patients following kidney transplantation, and in those with SLE, ${ }^{93-95}$ diabetes, ${ }^{96}$ Crohn's disease, ${ }^{97,98}$ ulcerative colitis and osteoarthritis. ${ }^{99}$ Of particular note, a study by Perico et al. ${ }^{100}$ showed that pretransplant infusion of autologous MSCs can protect the transplanted kidney from graft dysfunction. All studies except the one in Crohn's disease ${ }^{98}$ showed some clinical benefit of MSC treatment. Based on these initial encouraging results, further investigations are in progress to improve the safety and efficacy of MSC therapy.

Mohamadnejad et al. ${ }^{101}$ and Kharaziha et al. ${ }^{102}$ have carried out successful phase I trials in liver failure and cirrhosis, respectively. Transplantation of autologous MSCs remarkably improved patients' quality of life and improved liver function. Another two phase II studies also demonstrated that infusion of MSCs increased serum albumin, reduced serum bilirubin and improved Mayo end-stage liver disease score in patients with liver failure. ${ }^{103,104}$

Until now, clinical trials are mostly focused on BM-MSCs, and this may be because it is the earliest and traditional investigated cell type. With the further exploration of MSCs from other tissue origins and the progress got from preclinical studies, more types of MSCs will be learned in clinical studies and provide multiple cell-type choice for immunomodulation therapy.

\section{Issues of MSCs in Immunomodulation Therapies}

In the majority of completed early pilot clinical trials, recipients of MSC therapy demonstrated good tolerance and improved clinical symptoms. ${ }^{105}$ Although results from these clinical trials indicate that MSC-based therapy is a promising strategy for immunomodulation, there remain many challenges to be overcome.

In 2009, Osiris therapeutics, Inc., reported their preliminary results for prochymal phase III GvHD trials (http://clinicaltrials. gov/show/NCT00366145; http://investor.osiris.com/releasedetail.cfm?ReleaselD = 407404) in 192 patients with GvHD. 


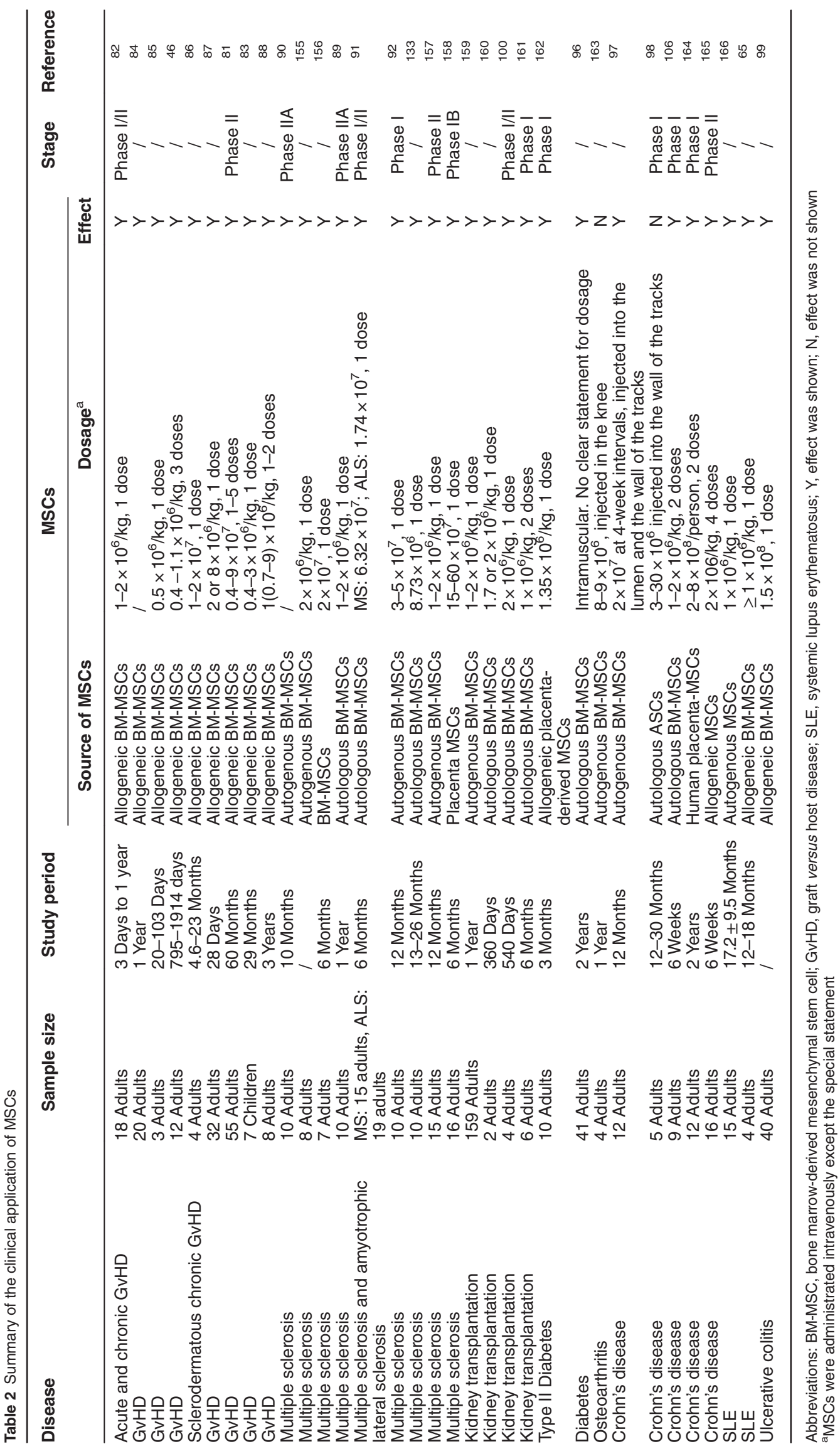


Unfortunately, there was no significant difference in clinical outcomes between the placebo control and allogeneic MSC groups. Conflicting results of MSC therapy have also been reported in the treatment of other conditions. For example, Duijvestein et al. ${ }^{106}$ reported that in six patients who received MSC infusions to treat Crohn's disease, only three exhibited decreased disease activity and in three the disease worsened. Similarly, Wang et al. ${ }^{93}$ showed that 12.5 and $16.7 \%$ of patients with SLE had disease relapse at 9 and 12 months respectively following MSC therapy. This suggests that repeat MSC transplantation might be required for a therapeutic effect. Of even more concern is the report of an association between MSC transplantation and a higher recurrence rate in patients with hematologic malignancy. ${ }^{107}$

Mixed results of MSCs in immunomodulation therapies. In order to adequately assess the benefit of MSCs as immunomodulation therapy, a significant amount of scientific data is required. Nonetheless, most published studies involve only small numbers of patients, and are fraught with a variety of differences in terms of MSC origin, preparation and delivery methods. The current widespread application of MSCs also makes it difficult to compare and contextualize the results generated by various trials. Although paracrine signaling by MSCs for immunosuppression is a wellestablished concept, the molecular mechanisms that regulate the secretion of soluble factors remain a matter for debate. Hence, the signaling networks between MSCs and immune cells, which are key issues in modulating the immune response, require further mechanistic investigation. The modest immunosuppressive and short-term effects of MSC transplantation also need to be improved. Here we address the issues related to cell preparation and infusion.

Variability of MSCs derived from different sources and ages: As mentioned above, BM, adipose tissue and cord blood are the most common cell sources for MSC therapy. ${ }^{108}$ Nonetheless, MSCs that are employed in immunomodulation therapies may also be isolated from dental pulp, thymus, gingiva, saphenous vein ${ }^{58,108-110}$ and even fetal tissue or derived from pluripotent stem cells. ${ }^{16,111,112}$ For immunomodulation, the optimal source(s) of MSCs have not been conclusively determined.

MSCs derived from different tissues display distinct differentiation tendencies, paracrine potential and immune properties. Several studies have aimed to compare the immunomodulation actions of different MSCs. Ribeiro et al. ${ }^{113}$ compared the capacity of MSCs from umbilical cord matrix, adipose tissue and BM to suppress peripheral blood B, $T$ and NK cells. Their results showed that although adipose tissue-derived MSCs had a stronger inhibitory effect, umbilical cord matrix-derived MSCs had little effect on B and NK cells. Moreover, there was significant heterogeneity in the differentiating potential of MSCs from different sources and this may also influence their clinical application. ${ }^{114}$ Unfortunately, systematic evaluation of different kinds of MSCs in immunomodulation are lacking.

The age of MSCs may also have a major impact on their therapeutic efficacy. MSCs derived from old donors have shown altered membrane glycerophospholipid composition and functionality. ${ }^{115}$ The differentiation potential of cells also decreases with age. ${ }^{116}$ MSCs derived from young donors show a higher proliferation rate with lower oxidative damage and cell senescence. ${ }^{117}$

Inconsistent protocols for isolation method, cell culture, expansion conditions and cryopreservation: Different investigators have their own distinct methods for isolation and culturing of MSCs. ${ }^{105}$ It has been shown that culture conditions, such as fetal bovine serum, human supplements, cell seeding density and oxygen conditions, can all influence the quality, proliferation, senescence and the immunomodulation ability of the cells. ${ }^{118-123}$ In addition, clinical trials have used large amounts of MSCs that were cryopreserved and thawed before infusion, whereas preclinical trials have used growing MSCs in the logarithmic phase. This may have led to the diverse results: cryopreserved cells will have low viability or experience a heat shock response that reduces their immunosuppressive capacity. ${ }^{124,125}$ Even when cell phenotypes are similar, flawed MSCs may have a lower therapeutic effect than fresh MSCs because of functional defects. It is therefore critical to have a uniform standard when MSCs are cultured and expanded in vitro if cell damage is to be limited.

Cell dose, cell modification and injection frequency: There is great variation among clinical trials in the injected dosage of MSCs (ranging from $0.5 \times 10^{6}$ to $10 \times 10^{6} / \mathrm{kg}$ of the recipients or even higher) ${ }^{105}$ as well as the frequency (single versus multiple injections). ${ }^{81,88,126,127}$ Although MSCs are thought to be immunoprivileged, repeated infusion of mismatched MSCs has been reported to lead to alloimmunization and subsequent refractoriness in mice. ${ }^{128,129}$ These issues need to be addressed in the future design of clinical trials.

The modification of MSCs with cytokines or drugs (environment engineering) may improve their therapeutic efficacy. In GvHD therapy, MSCs pretreated with IFN- $\gamma$ were more effective than nontreated MSCs in suppressing GvHD and preventing mortality, even if their number was fivefold lower. ${ }^{130}$ It has also been shown that dexamethasone treatment can affect cytokine expression and inhibit the immunomodulation effect of MSCs. ${ }^{131}$ Therefore, the therapeutic potential of modified MSCs requires further exploration.

Cell transfusion pattern: MSCs used in GvHD therapy are administrated by systemic infusion. ${ }^{81,126,127,132}$ Contrary to this, administration has been more targeted in other disease conditions. For example, Yamout et al. ${ }^{92}$ and others treated multiple sclerosis patients with intrathecal MSC injections. ${ }^{133}$ Based on these findings, and in the further investigation of immune disorders, the curative effect of MSCs may be improved if they are delivered to patients via a more targeted approach, especially in the treatment of solid organ disease.

\section{Future Prospects in the Development of MSCs for Immunomodulation}

Clinical grade of MSCs derived from human pluripotent stem cells. Despite the availability of MSCs from adult/ newborn tissue, ${ }^{134,135}$ they have limited proliferative capacity, 
a large variability in cell quality derived from different donors and quickly lose their differentiation potential when cultured in vitro. ${ }^{116,136}$ All these factors limit their therapeutic benefit. $^{137,138}$ Prochymal (BM-MSCs) has yet to be granted approval from US FDA, partly because of inconsistent immunosuppression results. These controversial outcomes are thought to be largely attributed to wide variation in BMMSC preparations acquired from different donors. To overcome these disadvantages, MSCs have been derived from alternative sources such as fat, dental pulp, umbilical cord, placenta and human ESCs or iPSCs. Among these alternatives, human ESCs/iPSCs are the most valuable sources for MSC production with considerable advantages.

When compared with adult tissue-derived MSCs, human ESC/iPSC-MSCs reveal similar morphology and in vitro differentiation potential, ${ }^{139}$ but have marked differences in their age-related DNA methylation level. This means that human ESC/iPSC-MSCs have a higher proliferation and regenerative capacity. ${ }^{140}$ Studies have also shown that single cell colony-derived MSC lines from human pluripotent stem cells are not only as functional as BM-MSCs in terms of phenotype, tissue repair capability ${ }^{79,141}$ and antiinflammation, ${ }^{33}$ but also have less batch-to-batch variation and can be expanded for $>120$ population doublings without any obvious senescence or risk of transformation, ${ }^{142}$ thus offering an ideal source for mass production of MSCs. Besides, human ESC/iPSC-MSCs have been proved to have the similar or even stronger immunomodulation effect compared with the adult MSCs. ${ }^{16,19,33,79}$ More importantly, human ESCs/iPSC-MSCs are less sensitive to proinflammatory IFN- $\gamma$-induced HLA-II expression and have a stronger immune privilege for cell survival after transplantation, ${ }^{79,80}$ making them more effective and durable in clinical immunomodulation. Clinical grade human ESCs have been generated in GMP (good manufacturing practices) facilities, ${ }^{143}$ and several human ESC-derived therapeutic cells have been approved for clinical trials by the US FDA. Quality consistent and reproducible MSC generation from human ESCs has been established and can be well controlled and manipulated in culture conditions. Hence, human ESCs offer an unlimited and homogenous source for noninvasive production of MSCs. ${ }^{144}$ As for iPSCs, researchers from Japan have already applied them in human trials (http://www.nature. com/news/next-generation-stem-cells-cleared-for-humantrial-1.15897), and this means that they can be produced and serve as the next generation of clinical stem cells. Subsequently, many researchers have started exploring therapygrade iPSC-MSC differentiation and culture conditions. ${ }^{145}$ Therefore, it is feasible to establish clinical grade human ESC/ iPSC-MSCs using GMP as the universal cell source for clinical immunomodulation therapy. These pluripotent cell-derived MSCs are advantageous as they offer the possibility for mass production of cells that can be prepared as an 'off -the-shelf' format and as a 'stem cell drug' product for clinical and industrial applications.

In contrast to an academic setting, for clinical and industrial use, human ESC/iPSC-MSCs must be produced to a clinical grade standard. Clinical grade MSC production necessitates adhering to GMP to ensure that the 'cell drug' is safe, reproducible and efficient when it is delivered to patients. All parts of the process must be defined: the starting material (tissue origin, separation or enrichment procedures), cell culture density and medium (fetal calf serum or human serum, cytokines with serum-free medium for target). To reach the GMP standard, cells must be cultured in as close to a closed system as possible.

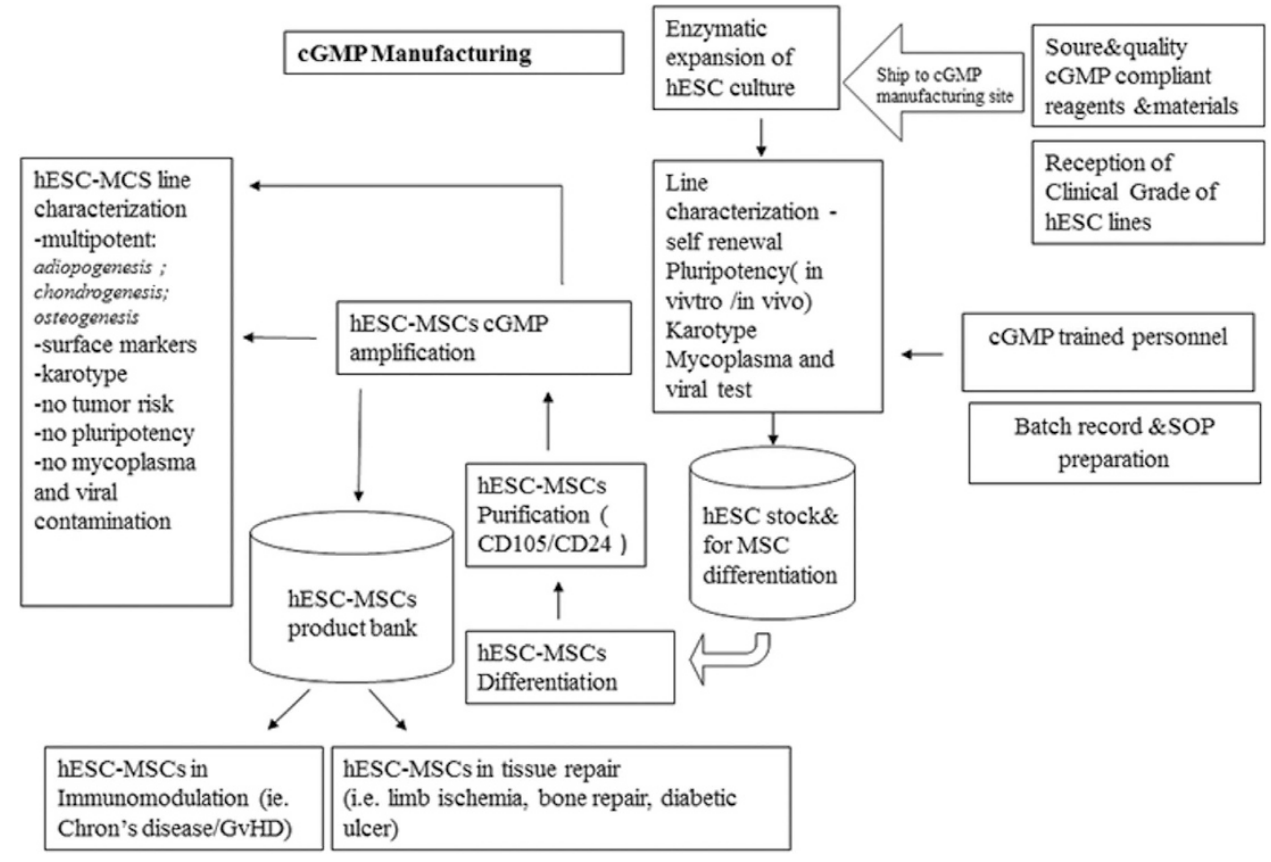

Figure 2 Establishing clinical grade hESC-MSC lines under cGMP facilities and protocols. All parts of the process must be defined and operated by professionals: the cell lines, the starting materials, cell culture density and medium. Cells must be cultured under the GMP standard. Phenotype, functional potential and microbiological safety of each batch of hESC-MSCs are tested. Scientific, rigorous and complete quality control of cells should be done before infusion 
For clinical trials, in order to get comparable therapeutic effects, the injected cells should be of similar condition. Quality control of cells is thus essential before infusion. We must consider the phenotype, functional potential and microbiological safety of the cells and ensure that cultured cells remain untransformed. In addition, quality assurance system procedures specific to the production of MSCs as a 'cell drug' must be determined and implemented. In summary, MSC therapy for immunomodulation necessitates ideal and universal cell sources, such as human ESC/iPSC-MSCs, and cells must be produced under GMP with scientific, rigorous and complete quality control (Figure 2).

Modification of MSCs. Preconditioning or genetic engineering of MSCs can promote the immunomodulation effect of MSC therapies. ${ }^{146-148}$ For the preconditioning of MSCs, IFN- $\gamma$ pretreatment enhances the immunomodulatory effect of MSCs by improving the cell-cell contact and the secretion of soluble factors related to immunosuppression. ${ }^{36,52,130}$ Other interesting approach is the induction of homing the MSC to the targeted site. Expression of the chemokine receptor 7 (CCR7) gene in MSCs can enhance their migration into secondary lymphoid organs, all major niches for generating immune responses or tolerance. Indeed, CCR7 gene engineering of MSCs has been shown to improve their immunomodulatory effect when used as therapy for GvHD. ${ }^{149}$ Nevertheless, the safety of gene vectors used in modification should be optimized to minimize their impact on the function of MSCs. If safety is guaranteed, MSCs can be conditioned or genetically modified before administration to achieve better effects.

\section{Conclusion}

MSCs are excellent candidates for therapeutic use as cellular therapies that can potentially revolutionize the current pharmaceutical landscape. Although they show great promise in the treatment of many immune disorders, the large variability in cell quality derived from different donors and tissues, inconsistent protocols, varying dosages and differing transfusion patterns can limit their therapeutic benefit. To overcome these hurdles, a careful evaluation of appropriate cell sources, more scientific data and a better mechanistic understanding of immunosuppression of MSCs is necessary. In the future, it is feasible to establish a clinical grade of human ESC /iPSC-MSCs using GMP to serve as the universal cell source for clinical immunomodulation therapy. Nonetheless, before this can be implemented, standardized protocols for cell culture, differentiation, expansion and cryopreservation as well as robust quality control systems need to be in place. These factors in combination with safely preconditioned and genetically modified MSCs may pave the way for the development of an effective cellular therapy for countless human immune disorders.

\section{Conflict of Interest}

The authors declare no conflict of interest.

Acknowledgements. We thank our colleagues for their input and scientific discussions. This research was supported by HKU Small Project Funding
(201409176221 to Z Zhang and 201409176251 to Q-L Lian); National Natural Science Foundation of China (No. 31270967; 31571407 to Q-L Lian, and 81322012, 81170896 and 81373174 to Q-L Fu), Shenzhen Technology Project (No. JCYJ20140828163633995 to Q-L Lian) and the key grant from the Science and Technology Foundation of Guangdong Province of China (2015B020225001 to Q-L Fu and Q Lian).

\section{Author contributions}

F Gao and SM Chiu wrote the manuscript; Z Zhang, DAL Motan, SM Chiu, Z Zhang and $L$ Chen organized data of the manuscript; $H-F$ Tse revised the manuscript; $Q-L$ Fu and $\mathrm{Q}$ Lian reorganized and revised the manuscript.

1. Uccelli A, Moretta L, Pistoia V. Immunoregulatory function of mesenchymal stem cells. Eur J Immunol 2006; 36: 2566-2573.

2. Siegel G, Schafer R, Dazzi F. The immunosuppressive properties of mesenchymal stem cells. Transplantation 2009; 87(9 Suppl): S45-S49.

3. Puissant B, Barreau C, Bourin P, Clavel C, Corre J, Bousquet C et al. Immunomodulatory effect of human adipose tissue-derived adult stem cells: comparison with bone marrow mesenchymal stem cells. Br J Haematol 2005; 129: 118-129.

4. Uccelli A, Pistoia V, Moretta L. Mesenchymal stem cells: a new strategy for immunosuppression? Trends Immunol 2007; 28: 219-226.

5. Sehmi R, Baatjes AJ, Denburg JA. Hemopoietic progenitor cells and hemopoietic factors: potential targets for treatment of allergic inflammatory diseases. Curr Drug Targets Inflamm Allergy 2003; 2: 271-278.

6. Denburg JA, Inman MD, Wood L, Ellis R, Sehmi R, Dahlback M et al. Bone marrow progenitors in allergic airways diseases: studies in canine and human models. Int Arch Allergy Immunol 1997; 113: 181-183.

7. Sehmi R, Denburg JA. Haemopoietic mechanisms in allergic rhinitis. Clin Exp Allergy 2005; 35: 1-3.

8. Denburg JA, Inman MD, Sehmi R, Uno M, O'Byrne PM. Hemopoietic mechanisms in allergic airway inflammation. Int Arch Allergy Immunol 1998; 117: 155-159.

9. Yanez R, Lamana ML, Garcia-Castro J, Colmenero I, Ramirez M, Bueren JA. Adipose tissue-derived mesenchymal stem cells have in vivo immunosuppressive properties applicable for the control of the graft-versus-host disease. Stem Cells 2006; 24 : 2582-2591.

10. Glennie S, Soeiro I, Dyson PJ, Lam EW, Dazzi F. Bone marrow mesenchymal stem cells induce division arrest anergy of activated T cells. Blood 2005; 105: 2821-2827.

11. Selmani Z, Naji A, Zidi I, Favier B, Gaiffe E, Obert L et al. Human leukocyte antigen-G5 secretion by human mesenchymal stem cells is required to suppress $T$ lymphocyte and natural killer function and to induce CD4+CD25highFOXP3+ regulatory T cells. Stem Cells 2008; 26: 212-222.

12. Corcione A, Benvenuto F, Ferretti E, Giunti D, Cappiello V, Cazzanti $F$ et al. Human mesenchymal stem cells modulate B-cell functions. Blood 2006; 107: 367-372.

13. Burchell JT, Strickland DH, Stumbles PA. The role of dendritic cells and regulatory T cells in the regulation of allergic asthma. Pharmacol Ther 2010; 125: 1-10.

14. Ramasamy R, Fazekasova H, Lam EW, Soeiro I, Lombardi G, Dazzi F. Mesenchymal stem cells inhibit dendritic cell differentiation and function by preventing entry into the cell cycle. Transplantation 2007; 83: 71-76.

15. Spaggiari GM, Capobianco A, Becchetti S, Mingari MC, Moretta L. Mesenchymal stem cellnatural killer cell interactions: evidence that activated NK cells are capable of killing MSCs, whereas MSCs can inhibit IL-2-induced NK-cell proliferation. Blood 2006; 107: 1484-1490.

16. Trivedi $P$, Hematti P. Derivation and immunological characterization of mesenchymal stromal cells from human embryonic stem cells. Exp Hematol 2008; 36: 350-359.

17. Yen BL, Chang CJ, Liu KJ, Chen YC, Hu HI, Bai CH et al. Brief report-human embryonic stem cell-derived mesenchymal progenitors possess strong immunosuppressive effects toward natural killer cells as well as T lymphocytes. Stem Cells 2009; 27: 451-456.

18. Tan Z, Su ZY, Wu RR, Gu B, Liu YK, Zhao XL et al. Immunomodulative effects of mesenchymal stem cells derived from human embryonic stem cells in vivo and in vitro. J Zhejiang Univ Sci B 2011; 12: 18-27.

19. Fu QL, Chow YY, Sun SJ, Zeng QX, Li HB, Shi JB et al. Mesenchymal stem cells derived from human induced pluripotent stem cells modulate T-cell phenotypes in allergic rhinitis. Allergy 2012; 67: 1215-1222.

20. Le Blanc K, Rasmusson I, Sundberg B, Gotherstrom C, Hassan M, Uzunel M et al. Treatment of severe acute graft-versus-host disease with third party haploidentical mesenchymal stem cells. Lancet 2004; 363: 1439-1441.

21. Rafei M, Campeau PM, Aguilar-Mahecha A, Buchanan M, Williams P, Birman E et al. Mesenchymal stromal cells ameliorate experimental autoimmune encephalomyelitis by inhibiting CD4 Th17 T cells in a CC chemokine ligand 2-dependent manner. J Immunol 2009; 182: 5994-6002.

22. Cho KS, Park HK, Park HY, Jung JS, Jeon SG, Kim YK et al. IFATS collection: immunomodulatory effects of adipose tissue-derived stem cells in an allergic rhinitis mouse model. Stem Cells 2009; 27: 259-265.

23. Cho KS, Roh HJ. Immunomodulatory effects of adipose-derived stem cells in airway allergic diseases. Curr Stem Cell Res Ther 2010; 5: 111-115. 
24. Goodwin M, Sueblinvong V, Eisenhauer P, Ziats NP, LeClair L, Poynter ME et al. Bone marrow-derived mesenchymal stromal cells inhibit Th2-mediated allergic airways inflammation in mice. Stem Cells 2011; 29: 1137-1148.

25. Nemeth K, Keane-Myers A, Brown JM, Metcalfe DD, Gorham JD, Bundoc VG et al. Bone marrow stromal cells use TGF-beta to suppress allergic responses in a mouse model of ragweed-induced asthma. Proc Natl Acad Sci USA 2010; 107: 5652-5657.

26. Bonfield TL, Koloze M, Lennon DP, Zuchowski B, Yang SE, Caplan Al. Human mesenchymal stem cells suppress chronic airway inflammation in the murine ovalbumin asthma model. Am J Physiol Lung Cell Mol Physiol 2010; 299: L760-L770.

27. Bonfield TL, Nolan Koloze MT, Lennon DP, Caplan Al. Defining human mesenchymal stem cell efficacy in vivo. J Inflamm 2010; 7: 51.

28. Crop MJ, Baan CC, Korevaar SS, ljzermans JN, Pescatori M, Stubbs AP et al. Inflammatory conditions affect gene expression and function of human adipose tissue-derived mesenchymal stem cells. Clin Exp Immunol 2010; 162: 474-486.

29. Raicevic G, Najar M, Najimi M, El Taghdouini A, van Grunsven LA, Sokal E et al. Influence of inflammation on the immunological profile of adult-derived human liver mesenchymal stromal cells and stellate cells. Cytotherapy 2015; 17: 174-185.

30. Ren G, Zhao X, Zhang L, Zhang J, L'Huillier A, Ling W et al. Inflammatory cytokine-induced intercellular adhesion molecule-1 and vascular cell adhesion molecule-1 in mesenchymal stem cells are critical for immunosuppression. J Immunol 2010; 184: 2321-2328.

31. Yagi H, Soto-Gutierrez A, Parekkadan B, Kitagawa Y, Tompkins RG, Kobayashi N et al. Mesenchymal stem cells: Mechanisms of immunomodulation and homing. Cell Transplant 2010; 19: 667-679.

32. Chabannes D, Hill M, Merieau E, Rossignol J, Brion R, Soulillou JP et al. A role for heme oxygenase- 1 in the immunosuppressive effect of adult rat and human mesenchymal stem cells. Blood 2007; 110: 3691-3694

33. Sun $Y Q$, Deng $M X, H e J$, Zeng $Q X$, Wen W, Wong DS et al. Human pluripotent stem cell-derived mesenchymal stem cells prevent allergic airway inflammation in mice. Stem Cells 2012; 30: 2692-2699.

34. Krampera M, Cosmi L, Angeli R, Pasini A, Liotta F, Andreini A et al. Role for interferongamma in the immunomodulatory activity of human bone marrow mesenchymal stem cells. Stem Cells 2006; 24: 386-398.

35. Ryan JM, Barry F, Murphy JM, Mahon BP. Interferon-gamma does not break, but promotes the immunosuppressive capacity of adult human mesenchymal stem cells. Clin Exp Immunol 2007; 149: 353-363.

36. DelaRosa O, Lombardo E, Beraza A, Mancheno-Corvo P, Ramirez C, Menta R et al. Requirement of IFN-gamma-mediated indoleamine 2,3-dioxygenase expression in the modulation of lymphocyte proliferation by human adipose-derived stem cells. Tissue Eng Part A 2009; 15: 2795-2806

37. Ren G, Zhang L, Zhao X, Xu G, Zhang Y, Roberts Al et al. Mesenchymal stem cellmediated immunosuppression occurs via concerted action of chemokines and nitric oxide. Cell Stem Cell 2008; 2: 141-150.

38. Tse WT, Pendleton JD, Beyer WM, Egalka MC, Guinan EC. Suppression of allogeneic T-cell proliferation by human marrow stromal cells: implications in transplantation. Transplantation 2003; 75: 389-397.

39. Jarvinen L, Badri L, Wettlaufer S, Ohtsuka T, Standiford TJ, Toews GB et al. Lung resident mesenchymal stem cells isolated from human lung allografts inhibit $\mathrm{T}$ cell proliferation via a soluble mediator. J Immunol 2008; 181: 4389-4396.

40. Ge W, Jiang J, Arp J, Liu W, Garcia B, Wang H. Regulatory T-cell generation and kidney allograft tolerance induced by mesenchymal stem cells associated with indoleamine 2,3dioxygenase expression. Transplantation 2010; 90: 1312-1320.

41. Terness $\mathrm{P}$, Bauer TM, Rose L, Dufter $\mathrm{C}$, Watzlik A, Simon $\mathrm{H}$ et al. Inhibition of allogeneic $T$ cell proliferation by indoleamine 2,3-dioxygenase-expressing dendritic cells: mediation of suppression by tryptophan metabolites. J Exp Med 2002; 196: 447-457.

42. Mazzoni A, Bronte V, Visintin A, Spitzer JH, Apolloni E, Serafini P et al. Myeloid suppressor lines inhibit T cell responses by an NO-dependent mechanism. J Immunol 2002; 168: 689-695.

43. Wang $Y$, Chen $X$, Cao W, Shi $Y$. Plasticity of mesenchymal stem cells in immunomodulation: pathological and therapeutic implications. Nat Immunol 2014; 15 : 1009-1016.

44. Sato K, Ozaki K, Oh I, Meguro A, Hatanaka K, Nagai T et al. Nitric oxide plays a critical role in suppression of T-cell proliferation by mesenchymal stem cells. Blood 2007; 109: 228-234.

45. Sioud M, Mobergslien A, Boudabous A, Floisand Y. Mesenchymal stem cell-mediated T cell suppression occurs through secreted galectins. Int J Oncol 2011; 38: 385-390.

46. Sioud M, Mobergslien A, Boudabous A, Floisand $Y$. Evidence for the involvement of galectin-3 in mesenchymal stem cell suppression of allogeneic T-cell proliferation. Scand J Immunol 2010; 71: 267-274.

47. Najar M, Raicevic G, Boufker HI, Fayyad-Kazan H, De Bruyn C, Meuleman N et al. Adipose-tissue-derived and Wharton's jelly-derived mesenchymal stromal cells suppress lymphocyte responses by secreting leukemia inhibitory factor. Tissue Eng Part A 2010; 16: 3537-3546.

48. Ward PA. The sepsis seesaw: seeking a heart salve. Nat Med 2009; 15: 497-498.

49. Han $\mathrm{KH}, \mathrm{Ro} \mathrm{H}$, Hong JH, Lee EM, Cho B, Yeom HJ et al. Immunosuppressive mechanisms of embryonic stem cells and mesenchymal stem cells in alloimmune response. Transplant Immunol 2011; 25: 7-15.
50. Krampera M, Glennie S, Dyson J, Scott D, Laylor R, Simpson E et al. Bone marrow mesenchymal stem cells inhibit the response of naive and memory antigen-specific $T$ cells to their cognate peptide. Blood 2003; 101: 3722-3729.

51. English K, Ryan JM, Tobin L, Murphy MJ, Barry FP, Mahon BP. Cell contact, prostaglandin $\mathrm{E}(2)$ and transforming growth factor beta 1 play non-redundant roles in human mesenchymal stem cell induction of CD4+CD25(High) forkhead box P3+ regulatory T cells. Clin Exp Immunol 2009; 156: 149-160.

52. Sheng $H$, Wang $Y$, Jin $Y$, Zhang $Q$, Zhang $Y$, Wang $L$ et al. A critical role of IFNgamma in priming MSC-mediated suppression of $\mathrm{T}$ cell proliferation through up-regulation of $\mathrm{B} 7-\mathrm{H} 1$. Cell Res 2008; 18: 846-857.

53. Najar M, Raicevic G, Fayyad-Kazan H, De Bruyn C, Bron D, Toungouz M et al. Immune-related antigens, surface molecules and regulatory factors in human-derived mesenchymal stromal cells: the expression and impact of inflammatory priming. Stem Cell Rev 2012; 8: 1188-1198.

54. Gieseke F, Bohringer J, Bussolari R, Dominici M, Handgretinger R, Muller I. Human multipotent mesenchymal stromal cells use galectin-1 to inhibit immune effector cells. Blood 2010; 116: 3770-3779.

55. Lee SH, Jang AS, Kwon JH, Park SK, Won JH, Park CS. Mesenchymal stem cell transfer suppresses airway remodeling in a toluene diisocyanate-induced murine asthma model. Allergy Asthma Immunol Res 2011; 3: 205-211.

56. Firinci F, Karaman M, Baran Y, Bagriyanik A, Ayyildiz ZA, Kiray M et al. Mesenchymal stem cells ameliorate the histopathological changes in a murine model of chronic asthma. Int Immunopharmacol 2011; 11: 1120-1126.

57. Firinci F, Karaman M, Baran Y, Bagriyanik A, Ayyildiz ZA, Kiray M et al. Mesenchymal stem cells ameliorate the histopathological changes in a murine model of chronic asthma. Int Immunopharmacol 2011; 11: 1120-1126.

58. Zhang Q, Shi S, Liu Y, Uyanne J, Shi Y, Shi S et al. Mesenchymal stem cells derived from human gingiva are capable of immunomodulatory functions and ameliorate inflammationrelated tissue destruction in experimental colitis. J Immunol 2009; 183: 7787-7798.

59. Bessout R, Semont A, Demarquay C, Charcosset A, Benderitter M, Mathieu N. Mesenchymal stem cell therapy induces glucocorticoid synthesis in colonic mucosa and suppresses radiation-activated T cells: new insights into MSC immunomodulation. Mucosal Immunol 2014; 7: 656-669.

60. Xiao J, Zhang C, Zhang Y, Zhang X, Zhao J, Liang J et al. Transplantation of adiposederived mesenchymal stem cells into a murine model of passive chronic immune thrombocytopenia. Transfusion 2012; 52: 2551-2558.

61. Zappia E, Casazza S, Pedemonte E, Benvenuto F, Bonanni I, Gerdoni E et al. Mesenchymal stem cells ameliorate experimental autoimmune encephalomyelitis inducing T-cell anergy. Blood 2005; 106: 1755-1761.

62. Zhou B, Yuan J, Zhou Y, Ghawji M Jr, Deng YP, Lee AJ et al. Administering human adipose-derived mesenchymal stem cells to prevent and treat experimental arthritis. Clin Immunol 2011; 141: 328-337.

63. Gonzalez MA, Gonzalez-Rey E, Rico L, Buscher D, Delgado M. Treatment of experimental arthritis by inducing immune tolerance with human adipose-derived mesenchymal stem cells. Arthritis Rheum 2009; 60: 1006-1019.

64. Liu Y, Mu R, Wang S, Long L, Liu X, Li R et al. Therapeutic potential of human umbilical cord mesenchymal stem cells in the treatment of rheumatoid arthritis. Arthritis Res The 2010; 12: R210.

65. Sun L, Akiyama K, Zhang H, Yamaza T, Hou Y, Zhao S et al. Mesenchymal stem cell transplantation reverses multiorgan dysfunction in systemic lupus erythematosus mice and humans. Stem Cells 2009; 27: 1421-1432.

66. Chang JW, Hung SP, Wu HH, Wu WM, Yang AH, Tsai HL et al. Therapeutic effects of umbilical cord blood-derived mesenchymal stem cell transplantation in experimental lupus nephritis. Cell Transplant 2011; 20: 245-257.

67. Sun JC, Pan K, Chen MS, Wang QJ, Wang H, Ma HQ et al. Dendritic cells-mediated CTLs targeting hepatocellular carcinoma stem cells. Cancer Biol Ther 2010; 10: 368-375.

68. Gu Z, Akiyama K, Ma X, Zhang H, Feng X, Yao G et al. Transplantation of umbilical cord mesenchymal stem cells alleviates lupus nephritis in MRL/pr mice. Lupus 2010; 19 1502-1514.

69. Guo J, Yang J, Cao G, Fan H, Guo C, Ma YE et al. Xenogeneic immunosuppression of human umbilical cord mesenchymal stem cells in a major histocompatibility complexmismatched allogeneic acute graft-versus-host disease murine model. Eur J Haemato 2011; 87: 235-243.

70. Oh DY, Cui P, Hosseini H, Mosse J, Toh BH, Chan J. Potently immunosuppressive 5 -fluorouracil-resistant mesenchymal stromal cells completely remit an experimental autoimmune disease. J Immunol 2012; 188: 2207-2217.

71. Morando S, Vigo T, Esposito M, Casazza S, Novi G, Principato MC et al. The therapeutic effect of mesenchymal stem cell transplantation in experimental autoimmune encephalomyelitis is mediated by peripheral and central mechanisms. Stem Cell Res Ther 2012; 3. 3 .

72. Liu XJ, Zhang JF, Sun B, Peng HS, Kong QF, Bai SS et al. Reciprocal effect of mesenchymal stem cell on experimental autoimmune encephalomyelitis is mediated by transforming growth factor-beta and interleukin-6. Clin Exp Immunol 2009; 158: 37-44.

73. Choi EW, Shin IS, Lee HW, Park SY, Park JH, Nam MH et al. Transplantation of CTLA4Ig gene-transduced adipose tissue-derived mesenchymal stem cells reduces inflammatory immune response and improves Th1/Th2 balance in experimental autoimmune thyroiditis. J Gene Med 2011; 13: 3-16. 
74. Yu J, Zheng C, Ren X, Li J, Liu M, Zhang L et al. Intravenous administration of bone marrow mesenchymal stem cells benefits experimental autoimmune myasthenia gravis mice through an immunomodulatory action. Scand J Immunol 2010; 72: 242-249.

75. Zhou Y, Yuan J, Zhou B, Lee AJ, Lee AJ, Ghawji M Jr et al. The therapeutic efficacy of human adipose tissue-derived mesenchymal stem cells on experimental autoimmune hearing loss in mice. Immunology 2011; 133: 133-140.

76. Wang D, Zhang H, Liang J, Gu Z, Ma X, Huang J et al. Effect of allogeneic bone marrowderived mesenchymal stem cells transplantation in a polyl:C-induced primary biliary cirrhosis mouse model. Clin Exp Med 2011; 11: 25-32.

77. Yang H, Aprecio RM, Zhou X, Wang Q, Zhang W, Ding Y et al. Therapeutic effect of TSG-6 engineered iPSC-derived MSCs on experimental periodontitis in rats: a pilot study. PLOS One 2014; 9: e100285.

78. Cheng PP, Liu XC, Ma PF, Gao C, Li JL, Lin YY et al. iPSC-MSCs combined with low-dose rapamycin induced islet allograft tolerance through suppressing Th1 and enhancing regulatory T-cell differentiation. Stem Cells Dev 2015; 24: 1793-1804.

79. Zhang Y, Liao S, Yang M, Liang X, Poon MW, Wong CY et al. Improved cell survival and paracrine capacity of human embryonic stem cell-derived mesenchymal stem cells promote therapeutic potential for pulmonary arterial hypertension. Cell Transplant 2012; 21: 2225-2239.

80. Sun YQ, Zhang Y, Li X, Deng MX, Gao WX, Yao $Y$ et al. Insensitivity of human iPS cellsderived mesenchymal stem cells to interferon-gamma -induced HLA expression potentiates repair efficiency of hind limb ischemia in immune humanized NOD SCID gamma mice. Stem Cells 2015; e-pub ahead of print 14 July 2015; doi:10.1002/stem.2094.

81. Le Blanc K, Frassoni F, Ball L, Locatelli F, Roelofs H, Lewis I et al. Mesenchymal stem cells for treatment of steroid-resistant, severe, acute graft-versus-host disease: a phase II study. Lancet 2008; 371: 1579-1586.

82. Perez-Simon JA, Lopez-Villar O, Andreu EJ, Rifon J, Muntion S, Campelo MD et al Mesenchymal stem cells expanded in vitro with human serum for the treatment of acute and chronic graft-versus-host disease: results of a phase I/II clinical trial. Haematologica 2011; 96: 1072-1076

83. Muller I, Kordowich S, Holzwarth C, Isensee G, Lang P, Neunhoeffer F et al. Application of multipotent mesenchymal stromal cells in pediatric patients following allogeneic stem cell transplantation. Blood Cells Mol Dis 2008; 40: 25-32.

84. Baron F, Lechanteur C, Willems E, Bruck F, Baudoux E, Seidel L et al. Cotransplantation of mesenchymal stem cells might prevent death from graft-versus-host disease (GVHD) without abrogating graft-versus-tumor effects after HLA-mismatched allogeneic transplantation following nonmyeloablative conditioning. Biol Blood Marrow Transplant 2010; 16 : 838-847.

85. Arima N, Nakamura F, Fukunaga $A$, Hirata $H$, Machida $H$, Kouno $S$ et al. Single intraarterial injection of mesenchymal stromal cells for treatment of steroid-refractory acute graft-versus-host disease: a pilot study. Cytotherapy 2010; 12: 265-268.

86. Zhou H, Guo M, Bian C, Sun Z, Yang Z, Zeng Y et al. Efficacy of bone marrow-derived mesenchymal stem cells in the treatment of sclerodermatous chronic graft-versus-host disease: clinical report. Biol Blood Marrow Transplant 2010; 16: 403-412.

87. Kebriaei P, Isola L, Bahceci E, Holland K, Rowley S, McGuirk J et al. Adult human mesenchymal stem cells added to corticosteroid therapy for the treatment of acute graftversus-host disease. Biol Blood Marrow Transplant 2009; 15: 804-811.

88. Ringden $\mathrm{O}$, Uzunel M, Rasmusson I, Remberger M, Sundberg B, Lonnies $\mathrm{H}$ et al. Mesenchymal stem cells for treatment of therapy-resistant graft-versus-host disease. Transplantation 2006; 81: 1390-1397.

89. Connick P, Kolappan M, Patani R, Scott MA, Crawley C, He XL et al. The mesenchymal stem cells in multiple sclerosis (MSCIMS) trial protocol and baseline cohort characteristics: an open-label pre-test: post-test study with blinded outcome assessments. Trials 2011; 12: 62.

90. Connick P, Kolappan M, Crawley C, Webber DJ, Patani R, Michell AW et al. Autologous mesenchymal stem cells for the treatment of secondary progressive multiple sclerosis: an open-label phase 2a proof-of-concept study. Lancet Neurol 2012; 11: 150-156.

91. Karussis D, Karageorgiou C, Vaknin-Dembinsky A, Gowda-Kurkalli B, Gomori JM, Kassis I et al. Safety and immunological effects of mesenchymal stem cell transplantation in patients with multiple sclerosis and amyotrophic lateral sclerosis. Arch Neurol 2010; 67: 1187-1194.

92. Yamout B, Hourani R, Salti H, Barada W, El-Hajj T, Al-Kutoubi A et al. Bone marrow mesenchymal stem cell transplantation in patients with multiple sclerosis: a pilot study. J Neuroimmunol 2010; 227: 185-189.

93. Wang D, Li J, Zhang Y, Zhang M, Chen J, Li X et al. Umbilical cord mesenchymal stem cell transplantation in active and refractory systemic lupus erythematosus: a multicenter clinical study. Arthritis Res Ther 2014; 16: R79.

94. Wang D, Zhang H, Liang J, Li X, Feng X, Wang $\mathrm{H}$ et al. Allogeneic mesenchymal stem cell transplantation in severe and refractory systemic lupus erythematosus: 4 years of experience. Cell Transplant 2013; 22: 2267-2277.

95. Carrion F, Nova E, Ruiz C, Diaz F, Inostroza C, Rojo D et al. Autologous mesenchymal stem cell treatment increased Tregulatory cells with no effect on disease activity in two systemic lupus erythematosus patients. Lupus 2010; 19: 317-322.

96. Lu D, Chen B, Liang Z, Deng W, Jiang Y, Li S et al. Comparison of bone marrow mesenchymal stem cells with bone marrow-derived mononuclear cells for treatment of diabetic critical limb ischemia and foot ulcer: a double-blind, randomized, controlled trial. Diabetes Res Clin Pract 2011; 92: 26-36.
97. Ciccocioppo R, Bernardo ME, Sgarella A, Maccario R, Avanzini MA, Ubezio C et al. Autologous bone marrow-derived mesenchymal stromal cells in the treatment of fistulising Crohn's disease. Gut 2011; 60: 788-798.

98. Garcia-OImo D, Garcia-Arranz M, Herreros D, Pascual I, Peiro C, Rodriguez-Montes JA. A phase I clinical trial of the treatment of Crohn's fistula by adipose mesenchymal stem cell transplantation. Dis Colon Rectum 2005; 48: 1416-1423.

99. Lazebnik LB, Kniazev OV, Konopliannikov AG, Parfenov Al, Ruchkina IN, Mikhailova ZF et al. [Allogeneic mesenchymal stromal cells in patients with ulcerative colitis: two years of observation]. Eksp Klin Gastroenterol 2010; 11: 3-15.

100. Perico N, Casiraghi F, Gotti E, Introna M, Todeschini M, Cavinato RA et al. Mesenchymal stromal cells and kidney transplantation: pretransplant infusion protects from graft dysfunction while fostering immunoregulation. Transpl Int 2013; 26: 867-878.

101. Mohamadnejad M, Alimoghaddam K, Mohyeddin-Bonab M, Bagheri M, Bashtar M, Ghanaati $\mathrm{H}$ et al. Phase 1 trial of autologous bone marrow mesenchymal stem cell transplantation in patients with decompensated liver cirrhosis. Arch Iran Med 2007; 10: 459-466.

102. Kharaziha $\mathrm{P}$, Hellstrom PM, Noorinayer B, Farzaneh $\mathrm{F}$, Aghajani $\mathrm{K}$, Jafari $\mathrm{F}$ et al. Improvement of liver function in liver cirrhosis patients after autologous mesenchymal stem cell injection: a phase I-II clinical trial. Eur J Gastroenterol Hepatol 2009; 21: 1199-1205.

103. Amer ME, El-Sayed SZ, El-Kheir WA, Gabr H, Gomaa AA, El-Noomani N et al. Clinical and laboratory evaluation of patients with end-stage liver cell failure injected with bone marrowderived hepatocyte-like cells. Eur J Gastroenterol Hepatol 2011; 23: 936-941.

104. El-Ansary M, Abdel-Aziz I, Mogawer S, Abdel-Hamid S, Hammam O, Teaema S et al. Phase II trial: undifferentiated versus differentiated autologous mesenchymal stem cells transplantation in Egyptian patients with HCV induced liver cirrhosis. Stem Cell Rev 2012; 8: 972-981.

105. Sharma RR, Pollock K, Hubel A, McKenna D. Mesenchymal stem or stromal cells: a review of clinical applications and manufacturing practices. Transfusion 2014; 54: 1418-1437.

106. Duijvestein M, Vos AC, Roelofs $H$, Wildenberg ME, Wendrich BB, Verspaget HW et al. Autologous bone marrow-derived mesenchymal stromal cell treatment for refractory luminal Crohn's disease: results of a phase I study. Gut 2010; 59: 1662-1669.

107. Ning $\mathrm{H}$, Yang $\mathrm{F}$, Jiang $\mathrm{M}$, Hu L, Feng $\mathrm{K}$, Zhang $\mathrm{J}$ et al. The correlation between cotransplantation of mesenchymal stem cells and higher recurrence rate in hematologic malignancy patients: outcome of a pilot clinical study. Leukemia 2008; 22: 593-599.

108. Galderisi U, Giordano A. The gap between the physiological and therapeutic roles of mesenchymal stem cells. Med Res Rev 2014; 34: 1100-1126.

109. Komada Y, Yamane T, Kadota D, Isono K, Takakura N, Hayashi $S$ et al. Origins and properties of dental, thymic, and bone marrow mesenchymal cells and their stem cells. PLoS One 2012; 7: e46436.

110. Covas DT, Piccinato CE, Orellana MD, Siufi JL, Silva WA Jr, Proto-Siqueira R et al. Mesenchymal stem cells can be obtained from the human saphena vein. Exp Cell Res 2005; 309: 340-344.

111. Patel J, Shafiee A, Wang W, Fisk NM, Khosrotehrani K. Novel isolation strategy to deliver pure fetal-origin and maternal-origin mesenchymal stem cell (MSC) populations from human term placenta. Placenta 2014; 35: 969-971.

112. Campagnoli C, Roberts IA, Kumar S, Bennett PR, Bellantuono I, Fisk NM. Identification of mesenchymal stem/progenitor cells in human first-trimester fetal blood, liver, and bone marrow. Blood 2001; 98: 2396-2402.

113. Ribeiro A, Laranjeira P, Mendes S, Velada I, Leite C, Andrade P et al. Mesenchymal stem cells from umbilical cord matrix, adipose tissue and bone marrow exhibit different capability to suppress peripheral blood B, natural killer and T cells. Stem Cell Res Ther 2013; 4: 125.

114. in 't Anker PS, Noort WA, Scherjon SA, Kleijburg-van der Keur C, Kruisselbrink AB, van Bezooijen RL et al. Mesenchymal stem cells in human second-trimester bone marrow, liver, lung, and spleen exhibit a similar immunophenotype but a heterogeneous multilineage differentiation potential. Haematologica 2003; 88: 845-852.

115. Kilpinen L, Tigistu-Sahle F, Oja S, Greco D, Parmar A, Saavalainen P et al. Aging bone marrow mesenchymal stromal cells have altered membranecomposition and functionality. J Lipid Res 2013; 54: 622-635.

116. Wagner W, Bork S, Horn P, Krunic D, Walenda T, Diehlmann A et al. Aging and replicative senescence have related effects on human stem and progenitor cells. PLoS One 2009; 4: e5846.

117. Stolzing A, Jones E, McGonagle D, Scutt A. Age-related changes in human bone marrowderived mesenchymal stem cells: consequences for cell therapies. Mech Ageing Dev2008; 129: 163-173.

118. Sundin M, Ringden O, Sundberg B, Nava S, Gotherstrom C, Le Blanc K. No alloantibodies against mesenchymal stromal cells, but presence of anti-fetal calf serum antibodies, after transplantation in allogeneic hematopoietic stem cell recipients. Haematologica 2007; 92 : $1208-1215$.

119. Bieback K, Hecker A, Kocaomer A, Lannert H, Schallmoser K, Strunk D et al. Human alternatives to fetal bovine serum for the expansion of mesenchymal stromal cells from bone marrow. Stem Cells 2009; 27: 2331-2341.

120. Shahdadfar A, Fronsdal K, Haug T, Reinholt FP, Brinchmann JE. In vitro expansion of human mesenchymal stem cells: choice of serum is a determinant of cell proliferation, differentiation, gene expression, and transcriptome stability. Stem Cells 2005; 23: $1357-1366$. 
121. Banfi A, Muraglia A, Dozin B, Mastrogiacomo M, Cancedda R, Quarto R. Proliferation kinetics and differentiation potential of ex vivo expanded human bone marrow stromal cells: implications for their use in cell therapy. Exp Hematol 2000; 28: 707-715.

122. Berniakovich I, Giorgio M. Low oxygen tension maintains multipotency, whereas normoxia increases differentiation of mouse bone marrow stromal cells. Int J Mol Sci 2013; 14: 2119-2134.

123. Yoo HS, Yi T, Cho YK, Kim WC, Song SU, Jeon MS. Mesenchymal stem cell lines isolated by different isolation methods show variations in the regulation of graft-versus-host disease. Immune Netw 2013; 13: 133-140.

124. Holubova M, Lysak D, Vlas T, Vannucci L, Jindra P. Expanded cryopreserved mesenchymal stromal cells as an optimal source for graft-versus-host disease treatment. Biologicals 2014; 42: 139-144.

125. Galipeau J. The mesenchymal stromal cells dilemma-does a negative phase III trial of random donor mesenchymal stromal cells in steroid-resistant graft-versus-host disease represent a death knell or a bump in the road? Cytotherapy 2013; 15: 2-8.

126. Herrmann R, Sturm M, Shaw K, Purtill D, Cooney J, Wright M et al. Mesenchymal stromal cell therapy for steroid-refractory acute and chronic graft versus host disease: a phase 1 study. Int J Hematol 2012; 95: 182-188.

127. Prasad VK, Lucas KG, Kleiner Gl, Talano JA, Jacobsohn D, Broadwater G et al. Efficacy and safety of ex vivo cultured adult human mesenchymal stem cells (Prochymal) in pediatric patients with severe refractory acute graft-versus-host disease in a compassionate use study. Biol Blood Marrow Transplant 2011; 17: 534-541.

128. Nauta AJ, Westerhuis G, Kruisselbrink AB, Lurvink EG, Willemze R, Fibbe WE Donor-derived mesenchymal stem cells are immunogenic in an allogeneic host and stimulate donor graft rejection in a nonmyeloablative setting. Blood 2006; 108: 2114-2120.

129. Eliopoulos N, Stagg J, Lejeune L, Pommey S, Galipeau J. Allogeneic marrow stromal cells are immune rejected by MHC class I- and class II-mismatched recipient mice. Blood 2005; 106: 4057-4065.

130. Polchert D, Sobinsky J, Douglas G, Kidd M, Moadsiri A, Reina E et al. IFN-gamma activation of mesenchymal stem cells for treatment and prevention of graft versus host disease. Eur J Immunol 2008; 38: 1745-1755.

131. Wang H, Pang B, Li Y, Zhu D, Pang T, Liu Y. Dexamethasone has variable effects on mesenchymal stromal cells. Cytotherapy 2012; 14: 423-430.

132. Perez-Simon JA, Lopez-Villar O, Andreu EJ, Rifon J, Muntion S, Diez Campelo M et al. Mesenchymal stem cells expanded in vitro with human serum for the treatment of acute and chronic graft-versus-host disease: results of a phase I/II clinical trial. Haematologica 2011; 96: 1072-1076.

133. Mohyeddin Bonab M, Yazdanbakhsh S, Lotfi J, Alimoghaddom K, Talebian F, Hooshmand F et al. Does mesenchymal stem cell therapy help multiple sclerosis patients? Report of a pilot study. Iran J Immunol 2007; 4: 50-57.

134. Wang HS, Hung SC, Peng ST, Huang CC, Wei HM, Guo YJ et al. Mesenchymal stem cells in the Wharton's jelly of the human umbilical cord. Stem Cells 2004; 22: 1330-1337.

135. Lee RH, Kim B, Choi I, Kim H, Choi HS, Suh K et al. Characterization and expression analysis of mesenchymal stem cells from human bone marrow and adipose tissue. Cell Physiol Biochem 2004; 14: 311-324.

136. Crisostomo PR, Wang M, Wairiuko GM, Morrell ED, Terrell AM, Seshadri P et al. High passage number of stem cells adversely affects stem cell activation and myocardial protection. Shock 2006; 26: 575-580.

137. Heeschen C, Lehmann R, Honold J, Assmus B, Aicher A, Walter DH et al. Profoundly reduced neovascularization capacity of bone marrow mononuclear cells derived from patients with chronic ischemic heart disease. Circulation 2004; 109: 1615-1622.

138. Roobrouck VD, Ulloa-Montoya F, Verfaillie CM. Self-renewal and differentiation capacity of young and aged stem cells. Exp Cell Res 2008; 314: 1937-1944.

139. Villa-Diaz LG, Brown SE, Liu Y, Ross AM, Lahann J, Parent JM et al. Derivation of mesenchymal stem cells from human induced pluripotent stem cells cultured on synthetic substrates. Stem Cells 2012; 30: 1174-1181.

140. Frobel J, Hemeda H, Lenz M, Abagnale G, Joussen S, Denecke B et al. Epigenetic rejuvenation of mesenchymal stromal cells derived from induced pluripotent stem cells. Stem Cell Rep 2014; 3: 414-422.

141. Lian Q, Zhang Y, Zhang J, Zhang HK, Wu X, Zhang Y et al. Functional mesenchymal stem cells derived from human induced pluripotent stem cells attenuate limb ischemia in mice. Circulation 2010; 121: 1113-1123.

142. Lian Q, Lye E, Suan Yeo K, Khia Way Tan E, Salto-Tellez M, Liu TM et al. Derivation of clinically compliant MSCs from CD105+, CD24- differentiated human ESCs. Stem Cells 2007; 25: 425-436.

143. Tannenbaum SE, Turetsky TT, Singer O, Aizenman E, Kirshberg S, llouz N et al. Derivation of xeno-free and GMP-grade human embryonic stem cells-platforms for future clinical applications. PLoS One 2012; 7: e35325.

144. Ausubel LJ, Lopez PM, Couture LA. GMP scale-up and banking of pluripotent stem cells for cellular therapy applications. Methods Mol Biol 2011; 767: 147-159.

145. Luzzani C, Neiman G, Garate X, Questa M, Solari C, Fernandez Espinosa D et al. A therapy-grade protocol for differentiation of pluripotent stem cells into mesenchymal stem cells using platelet lysate as supplement. Stem Cell Res Ther 2015; 6: 6.

146. Deak E, Seifried E, Henschler R. Homing pathways of mesenchymal stromal cells (MSCs) and their role in clinical applications. Int Rev Immunol 2010; 29: 514-529.
147. Ip JE, Wu Y, Huang J, Zhang L, Pratt RE, Dzau VJ. Mesenchymal stem cells use integrin beta1 not CXC chemokine receptor 4 for myocardial migration and engraftment. Mol Biol Cell 2007; 18: 2873-2882.

148. Haider H, Jiang S, Idris NM, Ashraf M. IGF-1-overexpressing mesenchymal stem cells accelerate bone marrow stem cell mobilization via paracrine activation of SDF-1alpha/CXCR4 signaling to promote myocardial repair. Circ Res 2008; 103 1300-1308.

149. Li H, Jiang Y, Jiang X, Guo X, Ning H, Li Y et al. CCR7 guides migration of mesenchymal stem cell to secondary lymphoid organs: a novel approach to separate GvHD from GvL effect. Stem Cells 2014; 32: 1890-1903.

150. Djouad F, Charbonnier LM, Bouffi C, Louis-Plence P, Bony C, Apparailly F et al, Mesenchymal stem cells inhibit the differentiation of dendritic cells through an interleukin-6dependent mechanism. Stem Cells 2007; 25: 2025-2032.

151. Su WR, Zhang QZ, Shi SH, Nguyen AL, Le AD. Human gingiva-derived mesenchymal stromal cells attenuate contact hypersensitivity via prostaglandin E2-dependent mechanisms. Stem Cells 2011; 29: 1849-1860.

152. Kavanagh $\mathrm{H}$, Mahon BP. Allogeneic mesenchymal stem cells prevent allergic airway inflammation by inducing murine regulatory T cells. Allergy 2011; 66: 523-531.

153. Ou-Yang HF, Huang Y, Hu XB, Wu CG. Suppression of allergic airway inflammation in a mouse model of asthma by exogenous mesenchymal stem cells. Exp Biol Med 2011; 236 $1461-1467$.

154. Park HK, Cho KS, Park HY, Shin DH, Kim YK, Jung JS et al. Adipose-derived stromal cells inhibit allergic airway inflammation in mice. Stem Cells Dev 2010; 19: 1811-1818.

155. Odinak MM, Bisaga GN, Novitskii AV, Tyrenko VV, Fominykh MS, Bilibina AA et al. [Transplantation of mesenchymal stem cells in multiple sclerosis]. Zh Nevrol Psikhiatr Im SS Korsakova 2011; 111: 72-76.

156. Mohajeri M, Farazmand A, Mohyeddin Bonab M, Nikbin B, Minagar A. FOXP3 gene expression in multiple sclerosis patients pre- and post mesenchymal stem cell therapy. Iran J Allergy Asthma Immunol 2011; 10: 155-161.

157. Llufriu S, Sepulveda M, Blanco Y, Marin P, Moreno B, Berenguer J et al. Randomized placebo-controlled phase II trial of autologous mesenchymal stem cells in multiple sclerosis. PLoS One 2014; 9: e113936.

158. Lublin FD, Bowen JD, Huddlestone J, Kremenchutzky M, Carpenter A, Corboy JR et al. Human placenta-derived cells (PDA-001) for the treatment of adults with multiple sclerosis: a randomized, placebo-controlled, multiple-dose study. Mult Scler Relat Disord 2014; 3 : 696-704.

159. Tan J, Wu W, Xu X, Liao L, Zheng F, Messinger S et al. Induction therapy with autologous mesenchymal stem cells in living-related kidney transplants: a randomized controlled trial. JAMA 2012; 307: 1169-1177.

160. Perico N, Casiraghi F, Introna M, Gotti E, Todeschini M, Cavinato RA et al. Autologous mesenchymal stromal cells and kidney transplantation: a pilot study of safety and clinical feasibility. Clin J Am Soc Nephrol 2011; 6: 412-422.

161. Reinders ME, de Fijter JW, Roelofs H, Bajema IM, de Vries DK, Schaapherder AF et al. Autologous bone marrow-derived mesenchymal stromal cells for the treatment of allograft rejection after renal transplantation: results of a phase I study. Stem Cells Transl Med 2013; 2: $107-111$.

162. Jiang R, Han Z, Zhuo G, Qu X, Li X, Wang X et al. Transplantation of placentaderived mesenchymal stem cells in type 2 diabetes: a pilot study. Front Med 2011; 5 : 94-100.

163. Davatchi F, Abdollahi BS, Mohyeddin M, Shahram F, Nikbin B. Mesenchymal stem cell therapy for knee osteoarthritis. Preliminary report of four patients. Int J Rheum Dis 2011; 14: 211-215.

164. Mayer L, Pandak WM, Melmed GY, Hanauer SB, Johnson K, Payne D et al. Safety and tolerability of human placenta-derived cells (PDA001) in treatment-resistant crohn's disease: a phase 1 study. Inflamm Bowel Dis 2013; 19: 754-760.

165. Forbes GM, Sturm MJ, Leong RW, Sparrow MP, Segarajasingam D, Cummins AG et al. A phase 2 study of allogeneic mesenchymal stromal cells for luminal Crohn's disease refractory to biologic therapy. Clin Gastroenterol Hepatol 2014; 12 64-71.

166. Liang J, Zhang H, Hua B, Wang H, Lu L, Shi S et al. Allogenic mesenchymal stem cells transplantation in refractory systemic lupus erythematosus: a pilot clinical study. Ann Rheum Dis 2010; 69: 1423-1429.

Cell Death and Disease is an open-access journal published by Nature Publishing Group. This work is licensed under a Creative Commons Attribution 4.0 International License. The images or other third party material in this article are included in the article's Creative Commons license, unless indicated otherwise in the credit line; if the material is not included under the Creative Commons license, users will need to obtain permission from the license holder to reproduce the material. To view a copy of this license, visit http://creativecommons.org/licenses/by/4.0/ 